Svitlana Zuikina, PhD, Associate Professor, Department of Drugs Technology, National University of Pharmacy, Pushkinska str., 53, Kharkiv, Ukraine, 61002

E-mail: zujkin.svetlana@gmail.com

Alla Kovaleva, Doctor of Pharmacy, Professor, Department of Pharmacognosy, National University of Pharmacy, Pushkinska str., 53, Kharkiv, Ukraine, 61002

E-mail: allapharm@yahoo.com

Liliia Vyshnevska, Doctor of Pharmacy, Professor, Department of Drugs Technology, National University of Pharmacy, Pushkinska str., 53, Kharkiv, Ukraine, 61002

E-mail: liliiavyshnevska@gmail.com

УДК 616.379:616.831:661.98:577.175.3

DOI: 10.15587/2519-4852.2018.145725

\title{
REDOX-DEPENDENT MECHANISMS OF BRAIN NEUROPROTECTION OF RATS WITH EXPERIMENTAL DIABETES MELLITUS
}

\author{
(C) O. Temirova, M. Khaitovych, A. Burlaka, A. Vovk
}

мета. Дослідити ефективність регулювання редокс-залежних механізмів нейропротекиії різних фармакологічних схем $\mathrm{N}$-ацетилцистеїну (NAC) та мелатоніну (Mel) y головному мозку щурів 3 експериментальним иукровим діабетом 1 типу (ЦД 1).

Методи. Щури з індукованим ЦД 1 отримували NAC (1,5 г/кг), Mel (10 мг/кг) або їх комбінацію $(\mathrm{NAC}+\mathrm{Mel})$ протягом 5-ти тижнів. Стан електрон-транспортного ланцฺюга (ЕТЛ) мітохондрій, швидкість генерування супероксидних радикалів (CP), активність пNOS, концентрацію лактоферину, «вільного заліза», метгемоглобіну, 8-охоG в клітинах головного мозку шурів досліджували методом електронного парамагнітного резонансу (ЕПР) на комп'ютеризованому ЕПР-спектрометрі РЕ-1307 за температури рідкого азоту ( $T=77 K)$.

Результати. Через 7 тижнів після індукиії ЦД 1 швидкість генерування СР мітохондріями головного мозку щурів з ЦД 1 була значно вищою, а активність нейрональної NO-синтази (nNOS) зниженою, порівняно з групою контролю. Було встановлено зменшення активності Комплексу I ЕТЛ мітохондрій та зростання рівня 8-охоG, концентрачії «вільного заліза», NO-FeS-білків, концентрації лактоферину ma MetHb, в тканині головного мозку тварин з ЦД 1. Всі досліджувані фармакологічні схеми сприяли достовірному зниженню швидкості генерування CP та відновленню активності пNOS мітохондріями головного мозку. Фармакологічна корекиї NAC/Mel або NAC+Mel сприяла достовірному зниженню рівня 8-охоG та комплексів NO-FeS-білків, нормалізації активності комплексів "вільного заліза» тканини головного мозку шурів з ЦД 1. Терапія NАC також сприяла зменшенню рівня МеtНb, а комбінована терапія NAC+Mel - зменшенню рівня лактоферину головного мозку шурів з ЦД1.

Висновки. При індукиї ЦД 1 типу відбувається пошкодження ЕТЛ мітохондрій продуктами неповного розпаду глюкози, щчо проявляється зниженням синтезу АТФ, підвищенням рівня СР, які генеруються в наслідок порушення механізму транспорту електронів. Терапія NAC ma Mel чи їх комбінації супроводжувалася захистом клітин головного мозку щурів з ЦД 1 від токсичної дї СР, перешкоджаючи порушення функцій мітохондрій, щуо свідчить про нейропротективну дію. NAC та Меl є перспективними лікарськими засобами для профілактики та лікування діабетичної нейропатії

Ключові слова: иукровий діабет, головний мозок, оксидативний стрес, $N$-ацетилцистеїн, мелатонін, мітохондрії, супероксид

\section{Introduction}

Diabetes mellitus (DM) is one of the most common diseases with a steady tendency to increase, "a non-infectious epidemic of the 21 st century" [1]. It is projected that by 2030 the number of patients will reach 552 million $(9.9 \%$ or 1 diabetes patient in 10 healthy adults), and by 2035 - to 592 million (10.1\%) [2]. DM is one of the main causes of cerebrovascular complications. So, the risk of stroke, in patients with diabetes, is 3-4 times higher. In $10 \%$ of cases, vascular complications in patients with DM, lead to lethal effects [3]. The authors of numerous scientific papers in experimental and clinical studies have identified the leading role of oxygen and nitrogen radicals in the pathogenesis of diabetes and its complications, in particular, diabetic encephalopathy $[4,5]$. 
2. Formulation of the problem in a general way, the relevance of the theme and its connection with important scientific and practical issues

An important mechanism for the development of diabetic encephalopathy is the oxidative stress caused by hyperglycemia, which causes excessive formation of superoxide radicals (SR) and exhaustion of the antioxidant defense system [6]. Strengthening the generation of SR initiates the activation of 5 signaling pathways, which are involved in the pathogenesis of complications of diabetes. These include: increased formation of advanced glycation end-products (AGE), increased expression of AGE receptors, polyol glucose utilization, activation of protein kinase $\mathrm{C}$ isoforms, hyperactivity of the hexosamine pathological pathway [7]. Signal pathways activate apoptosis reactions and cause energy depletion, which leads to damage to neurons and the development of diabetic encephalopathy [8]. The role of autophagy, a dynamic process, which plays an important role in the regulation of cellular homeostasis by processing macromolecules and dysfunctional organelles, as well as various types of reactive oxygen species (ROS) $[9,10]$, is actively studied today.

\section{Analysis of recent studies and publications in which a solution of the problem are described and to which the author refers}

The brain cells are particularly susceptible to oxidative damage due to the increased oxygen metabolism, high lipid content and relative weakness of antioxidant defense [11]. Recent research has established the leading role of mitochondria in the ischemic injury of the brain in the launch of cascade of oxidative, morphofunctional neuronal disorders [11, 12]. Induced by hyperglycemia, accumulation with mitochondria of the ROS leads to disturbance of ion transport, impulse generation and conduction, rejection of reuptake of mediators (catecholamines, dopamine, serotonin), denovo protein synthesis disorder, reprogramming of energy-producing reactions, causing a significant decrease in energy reserves and loss of neurons [11]. Therefore, an important link of the cerebroprotective mechanism of action of modern durgs is their mitoprotective action.

To date, the role of $\mathrm{N}$-acetylcysteine (NAC), a synthetic drug with antioxidant properties, in the treatment of diseases of the central nervous system is widely studied [13]. Experimental studies indicate the ability of NAC to detect cerebroprotective effects under DM conditions [14].

Recent studies point to the ability of melatonin to influence the functioning of mitochondria, penetrating through membranes it stimulates antioxidant enzymes such as superoxide dismutase, catalase, glutathione peroxidase, glutathione reductase, which contributes to increased resistance to oxidative damage [15].

\section{The field of research considering the general problem, which is described in the article \\ Data on the neuroprotective effect of $\mathrm{N}$ -} acetylcysteine and melatonin are very fragmented. The NO- and CP-dependent mechanisms of cerebroprotection of $\mathrm{N}$-acetylcysteine and melatonin in case of DM 1 have not been studied sufficiently.

\section{Formulation of goals (tasks) of article}

The aim of the work was to study the effectiveness of regulation of redox-dependent mechanisms of neuroprotection processes of NAC and Mel various pharmacological schemes, in the brain of rats with experimental DM 1.

6. Presentation of the main research material (methods and objects) with the justification of the results

Experiments were carried out on 35 adult male Wistar rats weighing 200-260 g, grown in vivarium of the National Medical University named after O.O. Bogomolets. All manipulations on animals have been carried out in accordance with the Law of Ukraine No. 3447-IV "On the protection of animals from cruel treatment" and in accordance with the "Directive of the European Union of $2010 / 10 / 63$ of the EU on the Protection of vertebrates used for experimental and other scientific purposes" [16]. Compliance with the bioethical principles, while working with laboratory animals, is certified by the expert opinion of the Ethics Committee of the NMU named after O.O. Bohomolets (protocol №99 dated 12/28/2016).

Animals were kept in the conditions of 12-hour daily regime (8: 00-20: 00 light and 20: 00-8: 00 - dark time of day), natural light, at room temperature (19$24{ }^{\circ} \mathrm{C}$ ), relative humidity $(50-65 \%)$ in standard plastic cages of 3-4 animals. They received a diet of feed mix and cooled boiled water as needed.

Type 1 diabetes mellitus was modeled by administration of streptozotocin (STZ) (Sigma, USA) at a dose of $50 \mathrm{mg} / \mathrm{kg}$ in citrate buffer solution $(\mathrm{pH} 4.5)$ once intraperitoneally according to guidelines [17]. The DM was monitored by blood glucose content, which was determined using the One Touch Select Simple Portable Meter (LifeScan, USA). After 72 hours, animals with persistent hyperglycemia with a peripheral blood glucose index higher than $15 \mathrm{mmol} / \mathrm{l}$ were taken.

Animals were divided into 5 groups: 1 - control $(\mathrm{n}=7$; intact animals); $2-\mathrm{DM} 1 \quad(\mathrm{n}=7$; group of model animals with streptotrozine DM 1 receiving $0.9 \%$ physiological saline per os); 3 - NAC ( $n=7$; group of diabetic rats receiving $\mathrm{N}$-acetylcysteine (STADA) at a dose of $1.5 \mathrm{~g} / \mathrm{kg}$ per os); $4-\mathrm{Mel}(\mathrm{n}=7$; group of diabetic rats receiving melatonin (Kyiv Vitamin Factory) at a dose of $10 \mathrm{mg} / \mathrm{kg}$ per os); $5-\mathrm{NAC}+\mathrm{Mel}(\mathrm{n}=7$; group of model animals with streptozotocin DM 1 receiving a combination of $\mathrm{N}$-acetylcysteine $(1.5 \mathrm{~g} \mathrm{/} \mathrm{kg})$ and melatonin $(10 \mathrm{mg} / \mathrm{kg})$ ). Doses were selected according to literature sources $[18,19]$.

The investigational medicinal products were administered to experimental animals for 5 weeks, started 2 weeks after induction of DM.

We studied the changes in the functioning of the electron transport chain (ETL) of the mitochondria, the rate of SR generation, the activity of the neuronal NO synthase (nNOS), the concentration of lactoferrin, "free iron", methemoglobin (MetHb), and the level of 8oxoguanin in rat brain tissue cells. 
Changes in the functioning of the mitochondria ETL were determined by the location of the EPR signals ( $\mathrm{g}$ is the spectroscopic fraction factor), and the amplitude of the corresponding signal was measured. The studies were carried out by the method of electron paramagnetic resonance (EPR) in a low temperature $(77 \mathrm{~K})$ of biological material stabilization [20]. For this, $500 \mathrm{mg}$ of brain tissue was placed in a special mold and frozen in liquid nitrogen. The obtained tissue samples were investigated in a paramagnetic pure quartz diver on a computerized spectrometer RE-1307 with resonator $\mathrm{H} 011$ at a temperature of liquid nitrogen $(77 \mathrm{~K})$. The power of the microwave source was $40 \mathrm{~mW}$, the modulation frequency was $100 \mathrm{kHz}$ and the amplitude 10 Gaussian, the receiver's continuous time $\tau=0.3 \mathrm{sec}$. As a standard of intensity, a specially oriented sample of $\mathrm{Al}_{2} \mathrm{O}_{3}$ single crystal with a specific concentration of $\mathrm{Cr}^{3+}$ ions was used. The method of double integration evaluated the concentration of molecules by comparing the intensity of signals in EPR spectra with the intensity of the standard. Error in the method of spectrum integration and the spread of spectrum reproduction of one sample is not more than $3 \%$.

The rate of $\mathrm{SR}$ generation in the tissues was determined by the EPR method at room temperature in a paramagnetic clear quartz cell using a spin capture TEMPONE-H ("Sigma"). The activity of nNOS was determined by the EPR method using SpinTraps technology, as the spin trap was used by diethylthiocarbamate (Sigma) [21].

The molecular marker of oxidative DNA damage - 8-oxoguanine (8-oxoG) - was determined by analyzing ultraviolet spectra of eluates after their solid phase extraction from the brain [22].

The concentration of lactoferrin, "free iron", $\mathrm{MetHb}$, was investigated by EPR method at a temperature of liquid nitrogen (77 K) [21].

Statistical data processing was performed using variation statistics using the SPSS Statistics (version 22.0) program using AVONA single-factor analysis of variance with the Dunnet criterion for comparison groups with control and experimental groups. The normal distribution of variables was checked by the ShapiroVilka test. The spot evaluation of the results was presented in the form of average values and standard error of the mean $(\mathrm{X} \pm \mathrm{m})$. At the critical level of significance during the check of statistical hypotheses were taken $\mathrm{p}<0.05$.

The EPR brain specimens of rats with DM 1 and intact animals contain the following EPR signals, namely $\mathrm{g}=2.0$, which characterizes the level of $\mathrm{f}$ flavoubisemiquinones in ETL mitochondria; $\mathrm{g}=2.03$ level of formation of $\mathrm{NO}$ complexes with $\mathrm{FeS}$ proteins in ETL mitochondria; $g=1.94$-activity of the Fe-protein N-2 in the protein NAD - H-ubiquinone oxidoreductase electron transport complex of the respiratory chain of mitochondria.

7 weeks after the induction of DM 1, the rate of SR generation (Fig. 1a), in the mitochondria of the brain, in the group of animals with DM 1 was significantly higher compared with the control $(0.93 \pm 0.14 \mathrm{~nm} / \mathrm{g}$ tissue $-\min \mathrm{v} 0.15 \pm 0.05 \mathrm{~nm} / \mathrm{g}$ tissue $\cdot \min , \mathrm{p}<0.01)$. The activity of the neuronal NO synthase (nNOS) (Fig. $1 b)$, the brain of the rats with DM 1, was reduced compared to the control group of rats $(0.47 \pm 0.04 \mathrm{~nm} / \mathrm{g}$ tissue minus $1.2 \pm 0.09 \mathrm{~nm} / \mathrm{g}$ tissue $\cdot \min , \mathrm{p}<0.01)$. The analysis of changes in the rate of SR generation, after 5 weeks of pharmacotherapy, showed a statistically significant decrease compared with the group of diabetes mellitus ( $\mathrm{p}<0.05)$. Thus, the rate of SR generation when the NAC was set to $0.75 \pm 0.07 \mathrm{~nm} / \mathrm{g}$ tissue $\cdot \min$. Mel treatment caused a decrease in the rate of SR generation by $27.96 \%(0.67 \pm 0.09 \mathrm{~nm} / \mathrm{g}$ tissue $\min )$ and $40.86 \%$ $(0.55 \pm 0.08)$ combined therapy.

NAC induced an increase in nNOS activity in the mitochondria of the brain cells of diabetic rats $(0.7 \pm 0.05 \mathrm{~nm} / \mathrm{g}$ tissue minus vs. $0.47 \pm 0.04, \mathrm{p}<0.01)$. Mel therapy also contributed to an increase in the activity of nNOS $(0.87 \pm 0.1 \mathrm{~nm} / \mathrm{g}$ tissue $-\mathrm{min}, \mathrm{p}<0.01)$. The combined pharmacotherapy of NAC and Mel contributed to the growth of nNOS activity to $0.95 \pm 0.05 \mathrm{~nm} / \mathrm{g}$ tissue (min. $\mathrm{p}<0.01$ ) compared to the DM 1 group without treatment.

The level of 8-oxoG, a marker of oxidative damage to nucleic acids in rat brain cells, after 7 weeks of induction of DM 1, was significantly higher in comparison with the control group $(0.61 \pm 0.1 \mathrm{~nm} / \mathrm{g}$ of crude tissue versus $0.18 \pm 0.06, \quad \mathrm{p}<0.01)$. After pharmacological correction of $\mathrm{NAC} / \mathrm{Mel}$ or $\mathrm{NAC}+\mathrm{Mel}$, the level 8-oxoG (Fig. 2) was significantly lower in comparison with the group receiving the physiological solution $(\mathrm{p}<0.01)$. 

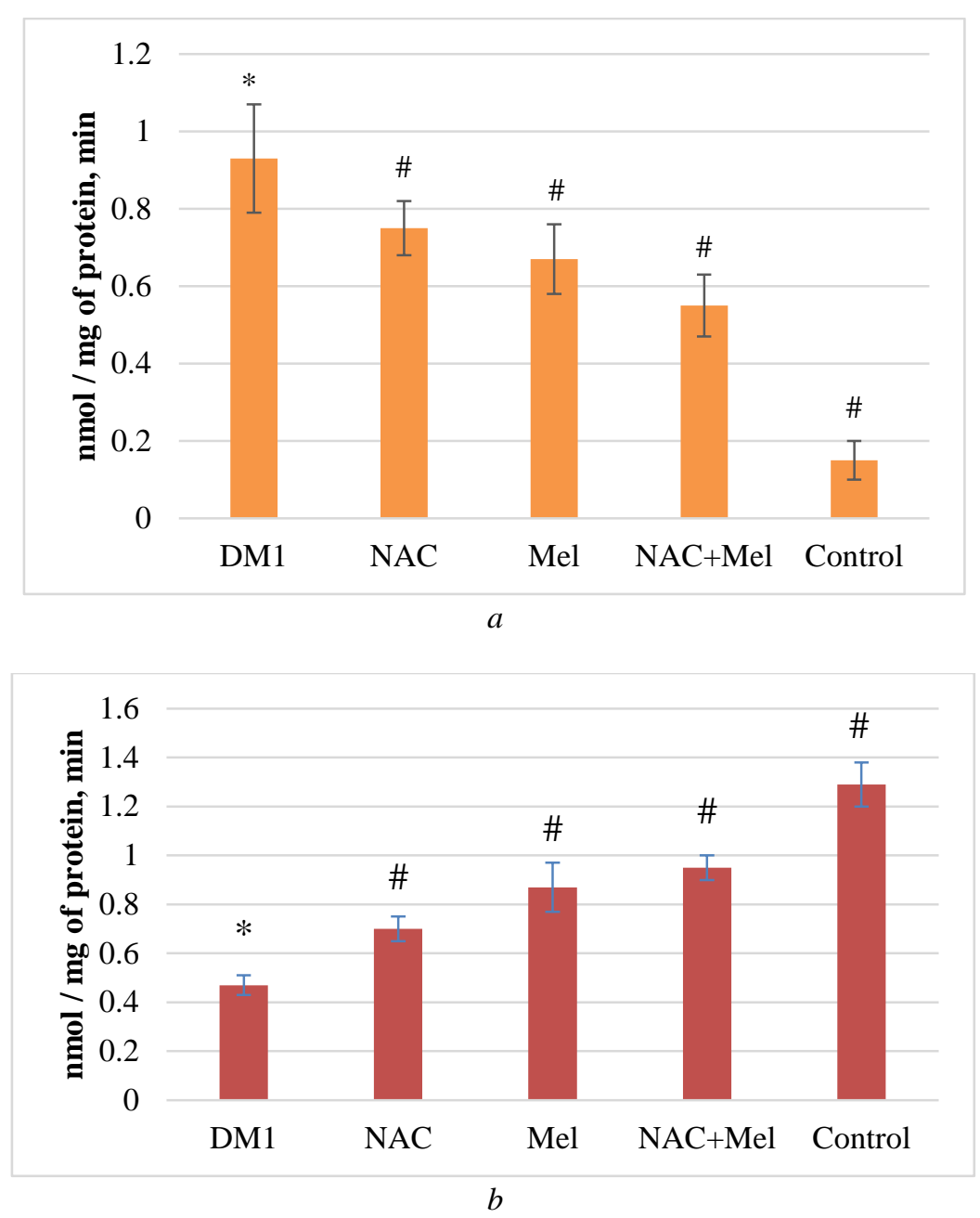

Fig. 1. Influence of N-acetylcysteine (NAC) and melatonin (Mel) on the rate of generation of superoxide radicals and nNOS activity in mitochondria of brain cells: $a$ - the rate of generation of superoxide radicals; $b-\mathrm{nNOS}$ activity. DM 1 (rats with diabetes mellitus 1 receiving physiological saline per os); NAC (rats with DM 1, administered NAC at a dose

of $1.5 \mathrm{~g} / \mathrm{kg}$ per os); Mel (rats with DM 1 receiving Mel in a dose of $10 \mathrm{mg} / \mathrm{kg}$ per os); NAC+Mel (diabetic rats receiving NAC and Mel per os combination therapy); control (intact rats). NAC / Mel or NAC+Mel was administered within 5 weeks. * in comparison with control, $\mathrm{p}<0.05$; \# in comparison with DM $1, \mathrm{p}<0.05$

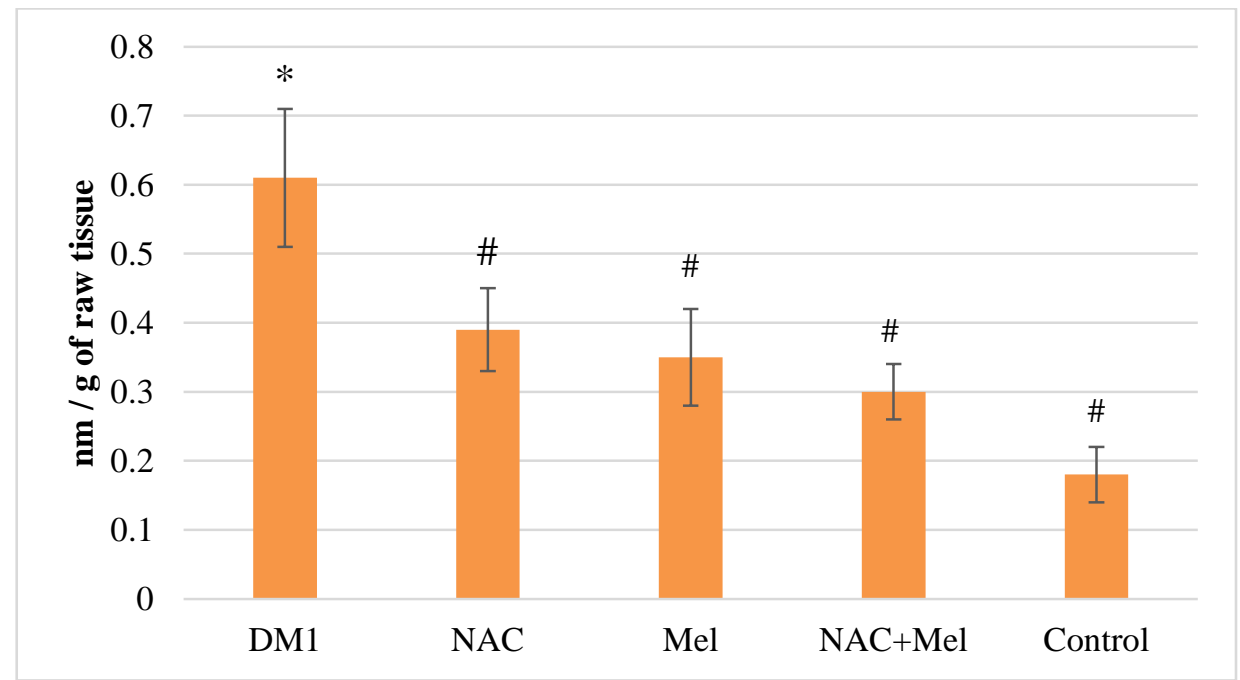

Fig. 2. Changes in the level of 8-oxoG in brain cells of diabetic rats that received a physiological solution and drugs. DM 1 (rats with diabetes mellitus 1 receiving physiological saline per os); NAC (rats with DM 1, administered NAC at a dose of $1.5 \mathrm{~g} / \mathrm{kg}$ per os); Mel (rats with DM 1 receiving Mel in a dose of $10 \mathrm{mg} / \mathrm{kg}$ per os); NAC+Mel (diabetic rats receiving NAC and Mel per os in combination therapy); control (intact rats). NAC / Mel or NAC+Mel were administered within 5 weeks. * in comparison with control, $\mathrm{p}<0.01$; \# in comparison with DM 1, $\mathrm{p}<0.01$ 
The damaging effect of DM 1 on ETL on the mitochondria of rat brain cells was manifested by the increase in the level of complexes of NO-FeS proteins (Fig. 3, a) to $0.097 \pm 0.007$ c.u., when compared with the control group $-0.05 \pm 0.02(\mathrm{p}<0.05)$. Increasing the level of the complex indicates the interaction of NO, synthesized nNOS, with FeS - proteins of mitochondria with a violation of the oxidative phosphorylation process. $\mathrm{NAC} / \mathrm{Mel}$ or $\mathrm{NAC}+\mathrm{Mel}$ therapy reduced the level of complexes of NO-FeS proteins, but the difference was not statistically significant ( $\mathrm{p}>0.05$ ).

The activity of the Complex I ETL of the rat mitochondria of the brain (Fig. 3, b) with DM 1 was $0.125 \pm 0.011$ c. u., which is 4.6 times lower than the control values $-0.58 \pm 0.07$ c.u. $(p<0.05)$. NAC therapy increased the activity of Complex I ETL mitochondria to $0.2 \pm 0.058$ c.u. (in 1.6 times more, in comparison with the group of DM $1(\mathrm{p}<0.05))$.
Pharmacorrection of $\mathrm{Mel}$ and $\mathrm{NAC}+\mathrm{Mel}$ also gave a positive result $(0.22 \pm 0.009$ doses and $0.25 \pm 0.006$ doses respectively) $(\mathrm{p}<0.05)$.

In cells of intact animals, the level of the ESR signal of the "free iron" complexes ("FI") was recorded within $0.08 \pm 0.004$ c. u., whereas in the brain cells of animals with DM 1 under the same conditions $1.357 \pm 0.176$ c. u. $(\mathrm{p}<0.01)$ (Fig. 4). Thus, for DM 1 there is an increase in oxidative processes due to the accumulation of "FI" complexes, increase in their content in the intercellular matrix, and the formation of an oxidizing phenotype. The introduction of investigated drugs contributed to the reduction of "FI" complexes $(\mathrm{p}<0.01)$. The values close to the control were observed in the group of animals receiving NAC $(0.158 \pm 0.008 \mathrm{c}$. u.). In the brain of animals receiving Mel, the levels of the "FI" complexes were 2.1 times smaller $(0.68 \pm 0.11 \mathrm{c}$. $\mathrm{u}$. ), and in animals receiving the combination therapy $\mathrm{NAC}+\mathrm{Mel}-3.7$ times $(0.325 \pm 0.034$ c. u. $)$.
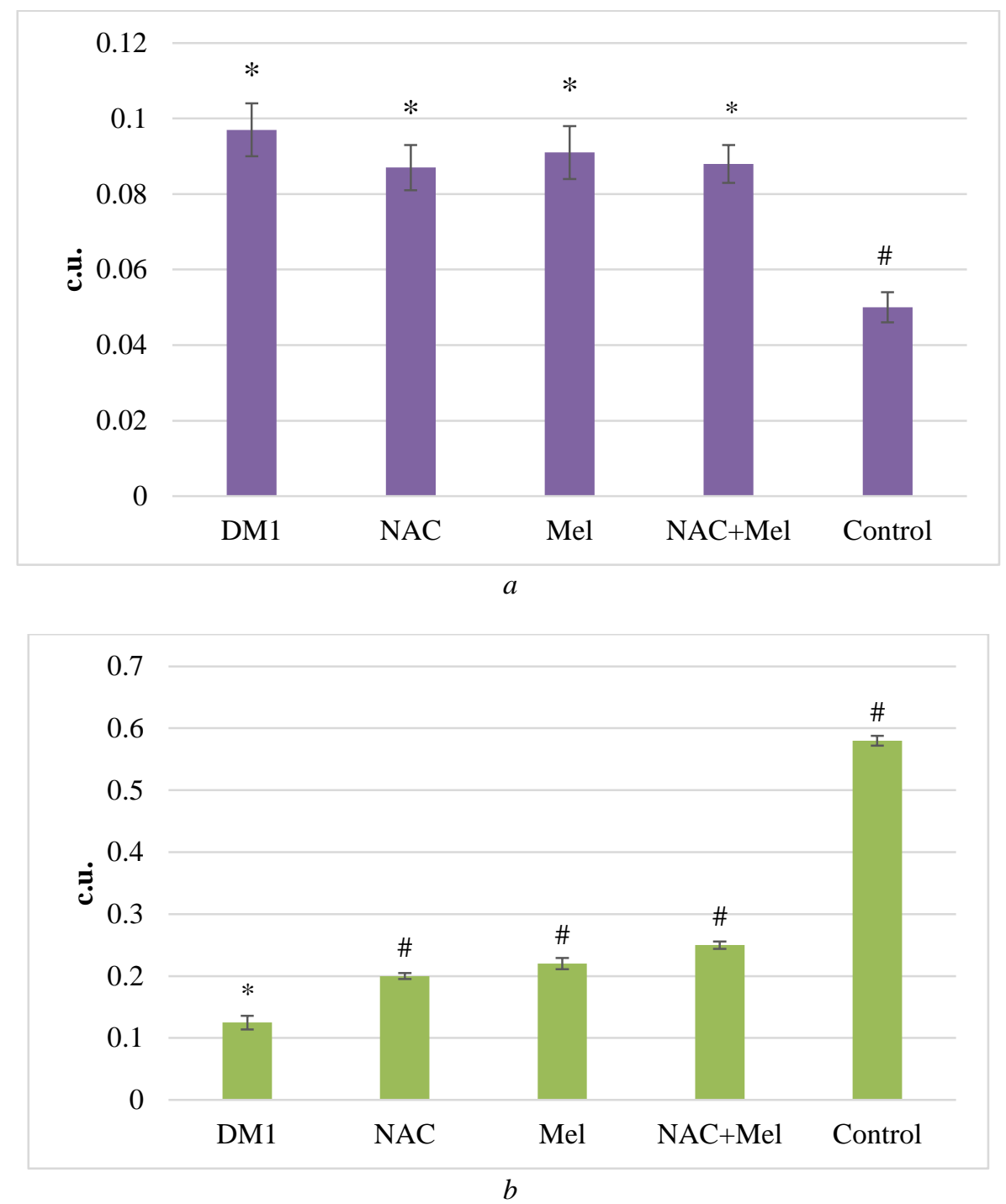

Fig. 3. Influence of N-acetylcysteine (NAC) and melatonin (Mel) on the level of complexes of NO-FeS-proteins and activity of complex I ETL of mitochondria of rat cell cultures: $a$ - level of complexes of NO-FeS proteins; $b$ - activity of complex I ETL mitochondria. DM 1 (rats with diabetes mellitus 1 receiving physiological saline per os); NAC (rats with DM 1, administered NAC at a dose of $1.5 \mathrm{~g} / \mathrm{kg}$ per os); Mel (rats with DM 1 receiving Mel in a dose of $10 \mathrm{mg} / \mathrm{kg}$ per os); NAC+Mel (diabetic rats receiving NAC and Mel per os combination therapy); control (intact rats). NAC/Mel or $\mathrm{NAC}+\mathrm{Mel}$ were administered within 5 weeks; * in comparison with control, $\mathrm{p}<0,05$;

\# in comparison with DM $1, \mathrm{p}<0.05$ 


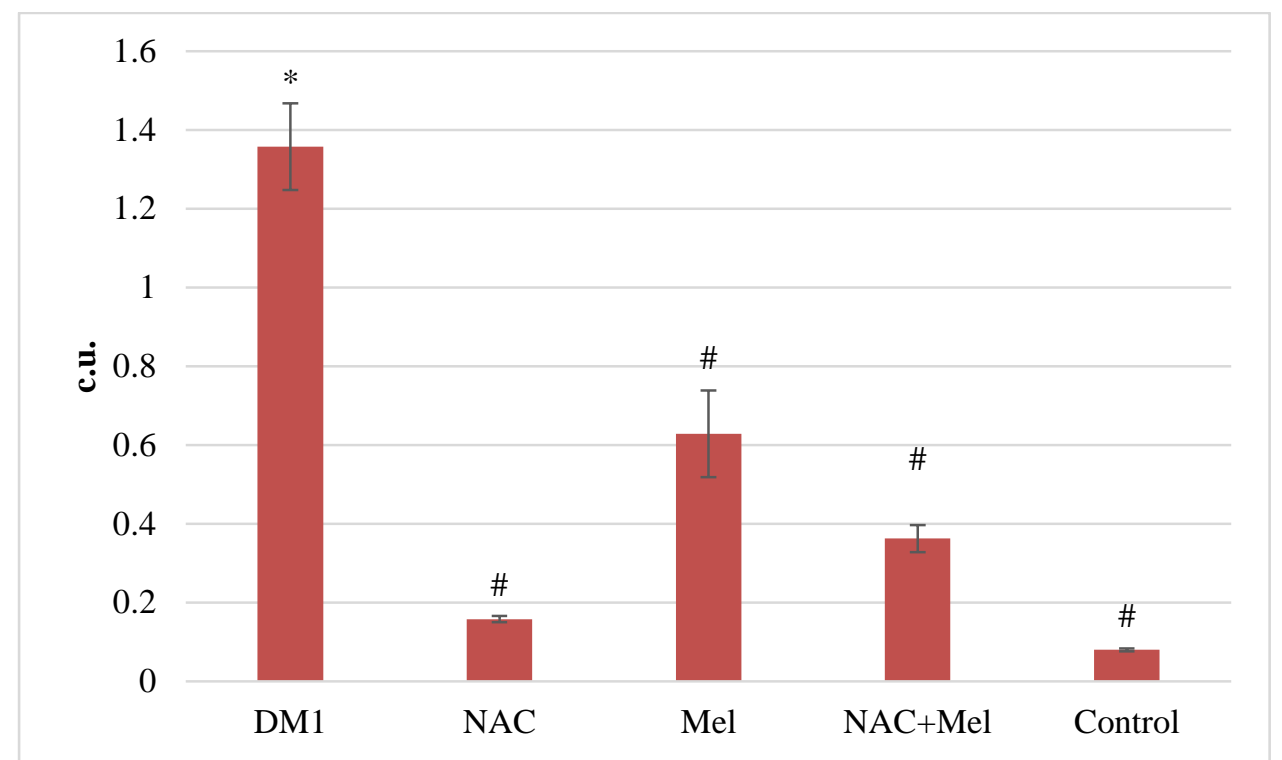

Fig. 4. Changes in the concentration of "free iron" complexes in brain cells of diabetic rats that received a physiological solution and medicinal substances. DM 1 (rats with DM 1 receiving physiological saline per os); NAC (rats with DM 1, administered NAC at a dose of $1.5 \mathrm{~g} / \mathrm{kg}$ per os); Mel (rats with DM 1, receiving Mel at a dose of $10 \mathrm{mg} / \mathrm{kg}$ per os);

$\mathrm{NAC}+\mathrm{Mel}$ (diabetic rats receiving NAC and Mel per os combination therapy); control (intact rats). NAC/Mel or $\mathrm{NAC}+\mathrm{Mel}$ were administered within 5 weeks; * in comparison with control, $\mathrm{p}<0,05$; \# in comparison with DM 1 , $\mathrm{p}<0.05$

It was also found that the level of flavoubisemiquinones in the brain of DM 1 animals receiving a physiological solution was $0.14 \pm 0.009$ c. u., whereas in the control group it was $0.35 \pm 0.05$ c. $u$. $(p<0.05)$. Only $\mathrm{NAC}+\mathrm{Mel}$ combination therapy had a statistically significant increase in the level of flavoubisemiquinones (0.28 \pm 0.008 c. u.).

In the brain cells of rats with DM 1, the concentration of lactoferrin (LF) was $0.16 \pm 0.019 \mathrm{spins} / \mathrm{g}$ of crude tissue, respectively, 14.8 times higher than the content of LF in the brain cells of intact rats, which was $0.078 \pm 0.01 \mathrm{spins} / \mathrm{g}$ of raw tissue $(\mathrm{p}<0.05)$. Combined $\mathrm{NAC}+\mathrm{Mel}$ therapy, unlike monotherapy, reduced the level of LF of the brain of rats from DM $1(0.09 \pm 0.011$ spins/g of crude tissue, $\mathrm{p}<0.05$ ).

In the cages of the brain of rats with DM 1, the level of MetHb was 9.6 times higher than the control group $(0.192 \pm 0.011$ vs. $0.020 \pm 0.002$ c. u., $p<0.05)$. NAC therapy contributed to a significant decrease in MetHb level in the brain of rats with DM $1(0.120 \pm 0.01$ c. u., $\mathrm{p}<0.05)$. Mel in monotherapy and in combination with NAC also reduced the MetHb level, but the values were not statistically significant $(0.155 \pm 0.015$ and $0.148 \pm 0.013$ c. u., $\mathrm{p}>0.05$ ).

According to literary sources, hyperglycemia leads to a disturbance of the ETC function of mitochondria and causes an increase in the generation of ROS. Since mitochondria are the main source of ROS, oxidative stress, induced by disturbances of mitochondrial functions, also contributes to the development of diabetic neuropathy [23]. Neurons use oxidative phosphorylation to meet energy needs, so changing the functioning of mitochondria leads to energy shortages and deaths of neurons. Violation of the functions of the neurons leads to an increase in the level of ROS, due to the leakage of electrons from ETC [24]. Under pathological conditions, with high glucose content inside the cell, more NADH and FADH2 are formed in the Krebs cycle and more electrons are transmitted to the electron transport chain. As a result, the intermembrane proton gradient increases to a certain limit after which further transport of electrons to complex III is blocked, turning the electrons back to the $\mathrm{Q}$ complex, which transports them one by one to molecular oxygen, thus forming the superoxide radical [7]. CP cause damage to mitochondrial DNA and proteins, which results in a breach of ETC and an additional increase in the amount of SR. In addition, NO can interact with $\mathrm{CP}$, which results in the formation of peroxynitrite that can induce lipid peroxidation and activate the cascade of events that results in DNA damage [25].

The obtained results indicate that the administration of various pharmacological schemes of NAC, Mel or their combination for 5 weeks to rats with streptozotocin DM 1 promotes the protection of mitochondria from oxidative damage. Pharmacotherapy caused a decrease in the rate of generation of SR $(p<0.05)$ and an increase in the activity of nNOS $(\mathrm{p}<0.01)$. Medicinal products helped to normalize the functioning of ETC mitochondria.

Mel plays an important role in the regulation of mitochondrial homeostasis. It reduces the generation of nitric oxide in mitochondria and supports the bioenergetic functions of cells. Mel is activator of antioxidant enzymes, in particular catalase, superoxide dismutase, glutathione reductase, and lipoxygenase inhibitor. It increases resistance to oxidative damage by stabilizing microsomal membranes [26]. Introduction of Mel in rats with experimental DM 2 contributed to improving the functioning of liver mitochondria due to increased activity of mitochondrial citrate synthase $(p<0.001)$, complex IV ETL $(p<0.05)$, normalization of 
phosphorylation coefficient $(\mathrm{p}<0.05)$. The authors note that therapy also led to an increase in the synthesis of ATP (p<0.05) [27]. Another study showed that Mel in a dose of $10 \mathrm{mg} / \mathrm{kg}$ contributes to the protection of mitochondria of adipose tissue, in experimental rats DM 2, from oxidative damage [28].

Introduction of NAC to streptozotocin-induced DM 1 rats at a dose of $1.5 \mathrm{~g} / \mathrm{kg}$ for 4 weeks contributed to a decrease in the rate of SR generation and an increase in $\mathrm{NO}(\mathrm{p}<0.01)$ by aortic mitochondria. It has been shown that in the liver, NAC also increased the rate of generation of CP while NO was reduced [7].

\section{Conclusions from the conducted research and prospects for further development of this field}

1. The rate of SR generation, the mitochondria of the brain cells of untreated rats with DM 1, was significantly higher compared to the control group $(0.93 \pm 0.14 \mathrm{~nm} / \mathrm{g}$ tissue minus vs $0.15 \pm 0.05 \mathrm{~nm} / \mathrm{g}$ tissue $\bullet$ $\min , \mathrm{p}<0.01)$.

2. There was a violation of the synthesis of nNOS in rat brain tissue from DM 1, which may be due to damage to NO synthase, or as a result of the interaction of NO with superoxide radicals, which leads to the formation of peroxynitrite. There was an increase in the formation of complexes of NO-FeS proteins $(0.097 \pm 0.007$ c. $u$., in the control $-0.05 \pm 0.02, p<0.05)$ indicating the interaction of NO synthesized by nNOS with FeS-proteins of mitochondria with process disturbance oxidative phosphorylation. A decrease in the activity of the Complex I ETL mitochondria was detected $(0,125 \pm 0.011 \mathrm{c}$. u., while in the control it was $0.58 \pm 0.07$ c. u., $\mathrm{p}<0.05)$.

3. Modeling of DM 1 in rats was accompanied by an increase in the level of 8-hunting G-marker oxidative damage to nucleic acids $(0.61 \pm 0.1 \quad \mathrm{~nm} /$ day/g vs $0.18 \pm 0.06, \mathrm{p}<0.01)$, activity of complexes "Free iron" $(1.357 \pm 0.176$ c. u., while in the control $-0,08 \pm 0,04$ c. u., $\mathrm{p}<0,01)$ concentration of lactoferrin $(0.16 \pm 0.019$ spins $/ g$ of raw tissue against $0.078 \pm 0.01$ spins $/ g$ of raw tissue $<0,05$ ) and MetHb $(0.192 \pm 0.011$ versus $0.020 \pm 0.002 \mathrm{rpm}$, $\mathrm{p}<0.05)$, in the brain tissue.

4. The administration of NAC, Mel, and their combination in rats with experimental DM 1 contributed to protecting the cells of the brain relative to the toxic effect of SR (the rate of SR generation was $0.75 \pm 0.07 \mathrm{~nm} / \mathrm{g}$ tissue $\cdot \min , 0.67 \pm 0.09 \mathrm{~nm} / \mathrm{g}$ tissue $\bullet$ $\min$, and $0.55 \pm 0.08 \mathrm{~nm} / \mathrm{g}$ tissue $\cdot \min , \mathrm{p}<0.05)$. The protective effect of the drugs was manifested by the growth of $\mathrm{nNOS}$ activity $(0.7 \pm 0.05,0.87 \pm 0.1$ and $0.95 \pm 0.05 \mathrm{~nm} / \mathrm{g}$ tissue $\bullet \mathrm{min}$, respectively, $\mathrm{p}<0.01$ ), preventing the progression of damage to neurons.

5. Pharmacological correction of NAC/Mel or $\mathrm{NAC}+\mathrm{Mel}$ contributed to a significant decrease in the level of 8 -oxoG $(0.39 \pm 0.06, \quad 0.35 \pm 0.07$ and $0.3 \pm 0.04 \mathrm{~nm} / \mathrm{g}$ of crude tissue, compared with DM 1 group without treatment $-0.61 \pm 0.1, \mathrm{p}<0.01$ ), increase in the activity of the complex I ETL mitochondria $(0.2 \pm 0.058,0.22 \pm 0.009$ and $0.25 \pm 0.006$ c. u., $p<0.05)$ normalization of the activity of the "FI" complexes of the brain tissue of rats from DM $1(0.158 \pm 0.008,0.682 \pm 0.11$ and $0.325 \pm 0.034$ c. u., $\mathrm{p}<0.05)$. Therapy also contributed to a reliable NAC a decrease in the level of MetHb $(0.192 \pm 0.011$ units, $p<0.05)$ and the combination therapy $\mathrm{NAC}+\mathrm{Mel}$, in contrast to monotherapy, contributed to a decrease in the molar LF of the brain of rats from DM 1 $(0.09 \pm 0.11$ spins $/ g$ of raw tissue, $\mathrm{p}<0.05)$.

6. NAC/Mel in monotherapy and combination therapy are promising drugs for the prevention and treatment of diabetic neuropathy.

\section{References}

1. World Health Organization. Global Report on Diabetes. World Health Organization. 2016. URL: http://apps.who.int/ iris/bitstream/handle/10665/204871/9789241565257_eng.pdf?sequence=1

2. Tkachenko V. I., Vydyborets N. V., Kovalenko O. F. Analiz poshyrenosti ta zakhvoriuvanosti na tsukrovyi diabet i yoho uskladnennia sered naselennia Ukrainy ta u Kyivskii oblasti za 2004-2013 rr. // Zdobutky klinichnoi i eksperymentalnoi medytsyny. 2014. Issue 2. P. 177-182.

3. Mathematical model of diabetic encephalopathy / Popruha A. A. et. al. // Wiad Lek. 2017. Vol. 70, Issue 5. P. 906-909. URL: https://www.ncbi.nlm.nih.gov/pubmed/29203738

4. Thakur P., Kumar A., Kumar A. Targeting oxidative stress through antioxidants in diabetes mellitus // Journal of Drug Targeting. 2018. Vol. 26, Issue 9. P. 766-776. doi: http://doi.org/10.1080/1061186x.2017.1419478

5. Johar D. R., Bernstein L. H. Biomarkers of stress-mediated metabolic deregulation in diabetes mellitus // Diabetes Research and Clinical Practice. 2017. Vol. 126. P. 222-229. doi: http://doi.org/10.1016/j.diabres.2017.02.023

6. Physiological Targets for the Treatment of Diabetic Encephalopathy / Vieira L. et. al. // Central Nervous System Agents in Medicinal Chemistry. 2017. Vol. 17, Issue 1. P. 78-86. doi: http://doi.org/10.2174/1871524916666160428111015

7. Study of superoxide- and NO-dependent protective mechanisms of $\mathrm{N}$-acetylcysteine and losartan in rat's aorta and liver under streptozoticin-induced type 1 diabetes mellitus / Sytnyk I. et. al. // ScienceRise: Pharmaceutical Science. 2017. Issue 6 (10). P. 25-31. doi: http://doi.org/10.15587/2519-4852.2017.119490

8. Mechanisms and pharmacology of diabetic neuropathy - experimental and clinical studies / Zychowska M. et. al. // Pharmacological Reports. 2013. Vol. 65, Issue 6. P. 1601-1610. doi: http://doi.org/10.1016/s1734-1140(13)71521-4

9. Autophagy: The missing link in diabetic neuropathy? / Yerra V. G. et. al. // Medical Hypotheses. 2016. Vol. 86. P. 120128. doi: http://doi.org/10.1016/j.mehy.2015.11.004

10. Deconvoluting the role of reactive oxygen species and autophagy in human diseases / Wen X. et. al. // Free Radical Biology and Medicine. 2013. Vol. 65. P. 402-410. doi: http://doi.org/10.1016/j.freeradbiomed.2013.07.013

11. Diabetes and the Brain: Oxidative Stress, Inflammation, and Autophagy / Muriach M. et. al. // Oxidative Medicine and Cellular Longevity. 2014. Vol. 2014. P. 1-9. doi: http://doi.org/10.1155/2014/102158

12. Doklinichne vyvchennia spetsyfichnoi aktyvnosti potentsiinykh likarskykh zasobiv pervynnoi ta vtorynnoi neiroprotektsii / Chekman I. S. et. al. Kyiv, 2016. 92 p.

13. Neuroprotective effects of $\mathrm{N}$-acetyl cysteine on primary hippocampus neurons against hydrogen peroxide-induced injury are mediated via inhibition of mitogen-activated protein kinases signal transduction and antioxidative action / Wu W. et. al. // Molecular Medicine Reports. 2018. Vol. 17, Issue 5. P. 6647-6654. doi: http://doi.org/10.3892/mmr.2018.8699 
14. Wang B., Yee Aw T., Stokes K. Y. N-acetylcysteine attenuates systemic platelet activation and cerebral vessel thrombosis in diabetes // Redox Biology. 2018. Vol. 14. P. 218-228. doi: http://doi.org/10.1016/j.redox.2017.09.005

15. Melatonin and human mitochondrial diseases / Rafieian-Kopaei M. et. al. // Journal of Research in Medical Sciences. 2017. Vol. 22, Issue 1. P. 2. doi: http://doi.org/10.4103/1735-1995.199092

16. Council Directive 2010/63/EU of 22 September 2010 on the protection of animals used for scientific purposes // Official Journal of the European Communities. 2010. Vol. L 276. P. 33-79.

17. Doklinichni doslidzhennia likarskykh zasobiv: metodychni rekomendatsii / ed. by Stefanov O. V. Kyiv: Avitsena, 2001. $528 \mathrm{p}$.

18. Kamboj S. S., Vasishta R. K., Sandhir R. N-acetylcysteine inhibits hyperglycemia-induced oxidative stress and apoptosis markers in diabetic neuropathy // Journal of Neurochemistry. 2010. Vol. 112, Issue 1. P. 77-91. doi: http://doi.org/10.1111/j.14714159.2009.06435.x

19. Negi G., Kumar A., Sharma S. S. Melatonin modulates neuroinflammation and oxidative stress in experimental diabetic neuropathy: effects on NF- $\mathrm{KB}$ and Nrf2 cascades // Journal of Pineal Research. 2010. Vol. 50, Issue 2. P. 124-131. doi: http://doi.org/10.1111/j.1600-079x.2010.00821.x

20. Electron Paramagnetic Resonance in the Experimental Oncology: Implementation Examples of the Conventional Approaches / Burlaka A. P. et. al. // BioNanoScience. 2016. Vol. 6, Issue 4. P. 431-436. doi: http://doi.org/10.1007/s12668-0160238-5

21. Superoxide and NO-dependent mechanisms of antitumor and antimetastatic effect of L-arginine hydrochloride and coenzyme Q10 / Burlaka A. P. et. al. // Experimental oncology. 2016. Vol. 38. P. 31-35.

22. Burlaka A. P., Sydoryk Ye. P. Radykalni formy kysniu ta oksydu azotu pry pukhlynnomu protsesi. Kyiv: Naukova dumka, 2006. 227 p.

23. Diabetic retinopathy pathogenesis and the ameliorating effects of melatonin; involvement of autophagy, inflammation and oxidative stress / Dehdashtian E. et. al. // Life Sciences. 2018. Vol. 193. P. 20-33. doi: http://doi.org/10.1016/j.lfs.2017.12.001

24. Mitochondrial dysfunction in glial cells: Implications for neuronal homeostasis and survival / Rose J. et. al. // Toxicology. 2017. Vol. 391. P. 109-115. doi: http://doi.org/10.1016/j.tox.2017.06.011

25. Diabetic Retinopathy, Superoxide Damage and Antioxidants / M. Santos J. et. al. // Current Pharmaceutical Biotechnology. 2011. Vol. 12, Issue 3. P. 352-361. doi: http://doi.org/10.2174/138920111794480507

26. Melatonin and human mitochondrial diseases / Rafieian-Kopaei M. et. al. // Journal of Research in Medical Sciences. 2017. Vol. 22, Issue 1. P. 2. doi: http://doi.org/10.4103/1735-1995.199092

27. Melatonin reduces hepatic mitochondrial dysfunction in diabetic obese rats / Agil A. et. al. // Journal of Pineal Research. 2015. Vol. 59, Issue 1. P. 70-79. doi: http://doi.org/10.1111/jpi.12241

28. Melatonin improves mitochondrial function in inguinal white adipose tissue of Zücker diabetic fatty rats / JimenézAranda A. et. al. // Journal of Pineal Research. 2014. Vol. 57, Issue 1. P. 103-109. doi: http://doi.org/10.1111/jpi.12147

Рекомендовано до публікації д-р фарм. наук, професор Косяченко К. Л. Дата надходження рукопису 11.09.2018

Olena Temirova, Postgraduate student, Department of Clinical Pharmacology and Clinical Pharmacy, Bogomolets National Medical University, T. Shevchenka blvd., 13, Kyiv, Ukraine, 01601

E-mail: olena.fitsner@nmu.ua

Mykola Khaitovych, MD, Professor, Head of Department, Department of Clinical Pharmacology and Clinical Pharmacy, Bogomolets National Medical University, T. Shevchenka blvd., 13, Kyiv, Ukraine, 01601

E-mail: mykola.khaitovych@nmu.ua

Anatoliy Burlaka, Doctor of Biological Sciences, Senior Researcher, Laboratory of Metastatic Microenvironment Problems. R. E. Kavetsky Institute of Experimental Pathology, Oncology and Radiobiology of National Academy of Sciences of Ukraine, Vasylkivska str., 45, Kyiv, Ukraine, 03022 E-mail: apburlaka@gmail.com

Anastasia Vovk, PhD, Researcher, Laboratory of Metastatic Microenvironment Problems, R. E. Kavetsky Institute of Experimental Pathology, Oncology and Radiobiology of National Academy of Sciences of Ukraine, Vasylkivska str., 45, Kyiv, Ukraine, 03022

E-mail: vovk_nastia@nas.gov.ua 